\title{
Variability in effect of climate change on rain-on-snow peak flow events in a temperate climate
}

\author{
Christopher G. Surfleet ， Desirèe Tullos
}

\begin{abstract}
S U M M A R Y
The frequency of rain-on-snow (ROS) hydrologic events, which produce high runoff volumes and lead to large-scale flooding and avalanching, are likely to change in the future as the types and timing of precipitation change. The relationship between ROS precipitation events and peak daily flow events $\geqslant 1$-year return were examined for historical and future runoff affected by climate change within the Santiam River Basin, Oregon. Historical streamflow records and modeled historical and future streamflow projections were analyzed for three sites across three elevation zones defined by the dominant precipitation types; rain, rain and snow transition, and snow. The results illustrate that, across elevation zones, historical peak daily flows $\geqslant 1$-year return have a high frequency $(>60 \%)$ of association with ROS. The historical association between peak daily flows and ROS is highest within the transient rain and snow elevation band $(350-1100 \mathrm{~m})$, with $80 \%$ and $100 \%$ of $\geqslant 1$ and $\geqslant 5$-year return peak flows associated with ROS, respectively. In a future with increased air temperature due to climate change, our results indicate that a decrease in the frequency of high peak flow ROS events will occur in the low and middle elevation zones while the frequency of ROS associated peak flows will increase in high elevation areas. The transition of winter precipitation from snow to rain is predicted to increase peak daily flows $<5-10$-year return interval and decrease peak daily flows $\geqslant 10$-year return in the middle to high elevation zones.
\end{abstract}

\section{Introduction}

Studies on hydrologic response to climate change in temperate climates generally predict that increases in atmospheric air temperature will result in a decreased winter snowpack and increased winter rainfall. The implications for future runoff include earlier flood runoff, lower spring snow-melt runoff, and subsequently lower summer baseflow runoff (e.g. Eckhardt and Ulbrich, 2003; Gellens and Roulin, 1998; Hamlet et al., 2010; Surfleet and Tullos, 2012; Yang et al., 2002). Several studies (e.g. Gellens and Roulin, 1998; Hamlet et al., 2010; Middelkoop et al., 2001) illustrate how the transition from snowmelt runoff to greater rain-forced runoff may result in increased extreme peak flow events and subsequent flooding. However, a feedback between the projected transition to rainfall and snowmelt that occurs during rain precipitation events, known as rain-on-snow (ROS) events, needs to be considered. The snowmelt in a ROS event provides an additional input of water for runoff beyond rain precipitation alone which can result in large-scale flooding and avalanching (e.g.
Ferguson, 2000; Marks et al., 1998; McCabe et al., 2007; Sui and Koehler, 2001)

In temperate climates, precipitation falls as snow or rain predominately in the winter and early spring, with water stored as snow in the lower or middle alpine regions (Sui and Koehler 2001). In the western United States, snow precipitation occurs most frequently at elevations greater than $1100 \mathrm{~m}$, while rain precipitation dominants below 350-400 m (e.g. Berris and Harr, 1987; Sui and Koehler, 2001). The 350-1100 m elevation range, known as the transient rain and snow zone (Berris and Harr, 1987), receives a mix of rain and snow depending on the air temperature of the precipitation event. The transient rain and snow zone has a high frequency of ROS events during winter; it is not uncommon for shallow snow cover to melt completely during rainstorms. ROS events are also common in the spring (Sui and Koehler, 2001) when rainfall on the winter snow cover accelerates the snowmelt process; if the rainfall is heavy and the snow is deep, flooding often occurs.

Changes in the historical frequency of ROS events, associated with increased air temperature from climate change, have been reported (McCabe et al., 2007; Ye et al., 2008). In the western United States, the frequency of ROS events was observed to generally decrease in lower elevation areas and increase in high elevation areas over the last 35-years (McCabe et al., 2007). The trend of reduced 
ROS frequency in low elevation areas appears to be related to a decrease in the number of snowfall days and amount of snow on the ground. In high latitude and arctic areas of Eurasia, ROS events have been shown to increase associated with warmer air temperatures (Ye et al., 2008).

In the Santiam River, Oregon (SRB), located within a temperate climate, the 100-year peak daily flow was predicted to decrease or not change due to projected climate change, yet the 1-year peak daily flow was predicted to increase (Surfleet and Tullos, 2012). The predicted increase in annual peak daily flows, coupled with the decrease in 100-year peak daily flows, corresponded with predicted decreases in winter snow and increased winter rain precipitation. In this study, the relationships between ROS events and peak flow magnitude and frequency, predicted for the future climate, were examined in the SRB. The objectives of the research were to: (1) investigate whether ROS events are related to the frequency or magnitude of historical extreme peak flows in the SRB to evaluate the importance of ROS processes in the generation of peak flows; (2) examine the spatial distribution of ROS event frequency change along elevation zones through time (historical, 2040, and 2080 time periods); and (3) assess whether extreme peak flow frequency and magnitude are likely to change associated with decreases in ROS events due to climate change.

\section{Methods}

\subsection{Study area}

The Santiam River basin (SRB) was the focus of study for uncertainty in hydrologic response to climate change (Surfleet and Tullos, 2012; Surfleet et al., 2012), providing a rich dataset for evaluation of extreme peak flow events. The $4700 \mathrm{~km}^{2}$ SRB is located on the western slopes of the Cascade Range in Oregon, USA (Fig. 1). The SRB has a large elevation range (50-3199 m), varying from high elevation alpine areas, to middle elevation dissected mountain terrain, and to low elevation foothills and alluvial areas at the confluence with the Willamette Valley, Oregon. The SRB has a temperate climate with the majority of precipitation occurring between October and June. The largest peak flow event on record for the basin was during February 1996, an ROS event (Marks et al., 1998).

The soils in the SRB are classified (NRCS, 2007) as 80\% in Hydrologic Group B, with moderate rates of water transmission (infiltration and drainage) and 20\% in Hydrologic Group A, with slow rates of water transmission. The precipitation across the SRB averages from 1000 to over $2500 \mathrm{~mm} /$ year from the outlet to the highest elevations of the basin (Oregon Climate Service, 2010). Furthermore, two hydrologically-distinct seasons exist in the basin, a wet season (November through April) during which approximately $85 \%$ of precipitation occurs, and a dry season (May through October) during which 15\% of precipitation occurs (NRCS, 2011).

Precipitation and geology vary with elevation in SRB. Precipitation shifts from predominately rain in a low elevation zone $(<350 \mathrm{~m})$ to primarily snow at a high elevation zone $(>1100 \mathrm{~m})$ with a mix of rain and snow in a middle elevation zone (350$1100 \mathrm{~m}$ ) (Fig. 1). The high elevation zone of the Santiam River is composed of High Cascades geology with runoff influenced by deep groundwater aquifers (Surfleet and Tullos, 2012; Tague et al., 2008). The low elevation zone of the watershed is influenced by groundwater associated with the Williamette Valley aquifer. The middle elevation zone has primarily Western Cascade geology, which has moderate to low hydraulic conductivities coupled with shallow soils that result in rapid subsurface flows and runoff (Tague et al., 2008).

Historical and future ROS events were analyzed for the SRB and three intensivelv-studied sub-basins, each representing one of the three elevational ranges: North Santiam below Boulder Creek (NFS) (primarily high elevation zone), South Santiam at Cascadia (SFS) (primarily middle elevation zone), and Thomas Creek (TCS) (mix of low and middle elevation zones) (Fig. 1). The study sub-basins provided representations of differences in geology, elevation zones, topography, groundwater response, and precipitation inputs (snow vs. rain) found across the SRB. The sub-basin sites were also selected based on the lack of regulation of streamflow by flood control dams, while streamflow at the most downstream site (Santiam River at Jefferson) is regulated by four dams, Detroit and Big Cliff dams on the North Fork Santiam River and Foster and Green Peter Dams on the South Fork Santiam River.

\subsection{Historical peak flows: Determining frequency of rain-on-snow events}

The frequency of ROS events for historical peak daily flow $\geqslant 1$ year return interval was evaluated for the three study sub-basins using long-term streamflow records (USGS, 2011) (Fig. 1). Daily snow water equivalent (SWE), precipitation, and maximum air temperature measurements were available for the time period 1986-2010 from four snowpack telemetry stations (SNOTEL) (USDA, 2011) in the SRB (Fig. 1). The four SNOTEL stations are located at elevations ranging from 800 to $1200 \mathrm{~m}$. A peak daily flow was defined as being associated with a ROS event if precipitation occurred (to exclude exclusively snowmelt runoff), maximum daily temperature was $>0{ }^{\circ} \mathrm{C}$, and a decrease in SWE was observed (e.g. Ferguson, 2000; Loukas et al., 2002; McCabe et al., 2007). Analysis was limited to peak daily streamflow of 1 year return interval or higher and only one peak daily flow per storm event was evaluated. For example, if precipitation was ongoing and two or more peak daily flows consecutively were $>1$-year return, only the highest peak daily flow was used. The frequency of ROS events was determined by percentage of the total number of peak daily flows $\geqslant 1$-year return and $\geqslant 5$-year return that were identified as ROS. The time period of evaluation was 1986-2010, the limit of SNOTEL measurements. The TCS streamflow measurement location was not operating for the water years 1988-2002 and thus a shorter period of evaluation was used.

\subsection{Future peak flows: Determining frequency of rain-on-snow events}

\subsubsection{Hydrologic modeling with GSFLOW}

The GSFLOW hydrologic model (Markstrom et al., 2008) was used for evaluating future extreme peak flows and SWE in the SRB. Only a brief description of our model set-up, parameter uncertainty, general circulation model (GCM) inputs, and model validation is provided; see Surfleet and Tullos (2012) for further details.

GSFLOW is a coupled groundwater and surface-water flow model based on the integration of the U.S. Geological Survey (USGS) Precipitation-Runoff Modeling System (PRMS) (Leavesley et al., 1983) and the USGS Modular Groundwater Flow Model (MODFLOW; Harbaugh, 2005). PRMS calculations are done with a semi-distributed approach with calculations performed at the scale of user defined hydrologic response units (HRU). Modflow is a finite difference, three-dimensional groundwater flow model. Flow is exchanged among the three regions of GSFLOW on the basis of interdependent equations that calculate flow and storage of water throughout the simulated hydrologic system (Markstrom et al., 2008). The first region includes the plant canopy, snowpack, impervious storage, and soil zone. The second region consists of streams and lakes. The subsurface or third region is beneath regions 1 and 2, which consists of the unsaturated and saturated zones.

Spatial parameters for input data to GSFLOW by HRU include elevation, area, basin area, aspect, latitude, longitude, land cover 

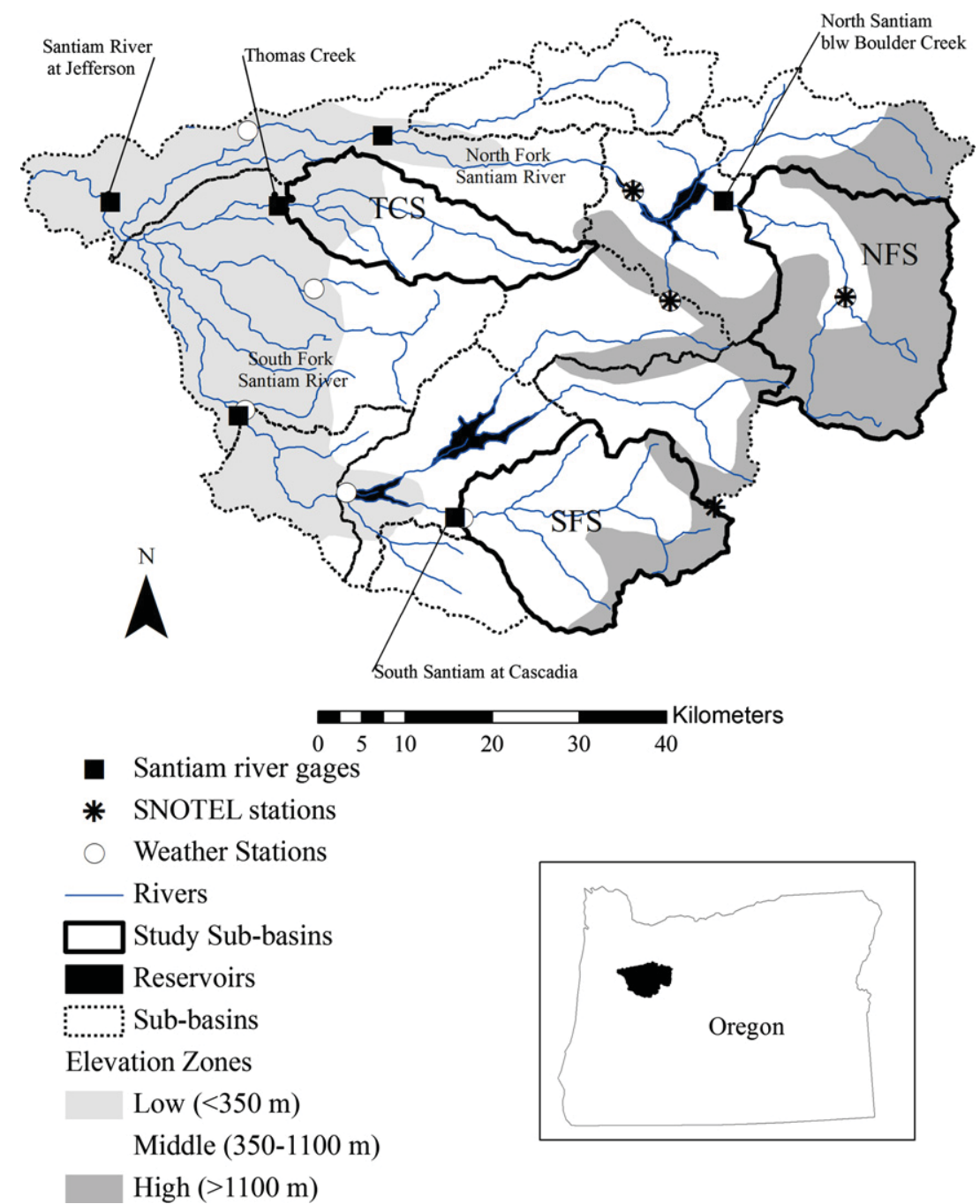

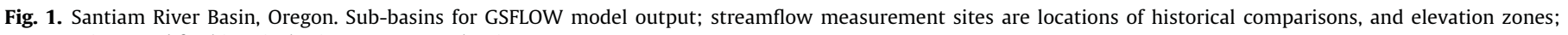
SNOTEL sites used for historical rain-on-snow evaluation.

type, and soil type. The spatial data came from a 30-m digital elevation model and land cover data (USGS, 2009) with soil information from NRCS (1986). Where groundwater modeling was done we developed a simple representation of the groundwater interactions, using $16 \mathrm{~km}^{2}$ grids for the finite difference calculations within MODFLOW. The sub-surface geologic information originated from McFarland (1983).

A formal Bayesian parameter uncertainty approach, the differential evolution adaptive metropolis (DREAM) (Vrugt et al., 2009), was used for determining behavioral posterior parameter distributions and assessing parameter uncertainty and equifinality in the GSFLOW simulations. The assessment of uncertainty focused on 34 parameters within the PRMS portion of the GSFLOW models. The 34 parameters were influential parameters of soil and geology hydraulic properties and forcing data corrections (precipitation multipliers and air temperature lapse rates) (Surfleet and Tullos, 2012). The development and validation of the GSFLOW parameter distributions were developed with historical streamflow records in the SRB from 1973 to 2010. The evaluation of parameter distributions using the DREAM uncertainty assessment was made separately for summer (dry time period May-October) and winter (wet time period November-April) time periods for each of three intensive study sub-basins (SFS, NFS, TCS). The seasonal parameterization was performed to account for the varying hydrologic conditions and processes associated with the high and low precipitation periods of the year (Surfleet and Tullos, 2012; Surfleet et al., 2012). GSFLOW parameter distributions were developed for the three study sub-basins then extrapolated to other sub-basins within the SRB with similar topographic and geologic characteristics (see Fig. 1 for sub-basin boundaries).

The GSFLOW modeling was forced by eight GCM simulations (Table 1) through the posterior distribution of parameters from the DREAM uncertainty assessment for two emission scenarios (B1 and A1B) (Surfleet and Tullos, 2012). The B1 and A1B emission

Table 1

Description of eight Global Circulation Models (GCM) used in this study (from Chang and Jung, 2010; Sufleet and Tullos, 2012).

\begin{tabular}{lll}
\hline GCM & Country of origin & References \\
\hline CCSM3 & United States & Collins et al. (2006) \\
CNRM-CM3 & France & Terray et al. (1998) \\
ECHAM5/MPI-OM & Germany & Jungclaus et al. (2006) \\
ECHO-5 & Germany/Korea & Min et al. (2005) \\
IPSL-CM4 & France & Marti et al. (2005) \\
MIROC3.2 & Japan & K-1 Developers (2004) \\
PCM & United States & Washington et al. (2000) \\
UKMO-HadCM3 & United Kingdom & Gordon et al. (2000) \\
\hline
\end{tabular}


scenarios represent increases in greenhouse gas emissions until the mid-century (2050) then declines due to more efficient technologies; the A1B scenario predicts more rapid global greenhouse gas emission than B1 (IPCC, 2007). The eight GCM simulations were prepared for the IPCC Fourth Assessment Report (IPCC, 2007) and results were statistically downscaled using the bias correction and spatial downscaling method (Wood et al., 2004; Hamlet et al., 2010) (provided by the Climate Impacts Group, University of Washington). The change in precipitation and mean daily air temperature from the downscaled GCM data, used as input to the GSFLOW modeling, is presented for the SRB as an average by B1 and A1B emission scenario for 2040 and 2080 time periods (Fig. 2).

The ensemble mean of the 2.5 , median, and 97.5 percentiles of GSFLOW output by scenario, B1 or A1B, was used to interpret uncertainties in the results. For results of percent change in peak flows and SWE, the change for the 2.5, median, and 97.5 percentiles was calculated by time period from the simulated historic value. GSFLOW simulations were performed for individual sub-basins; results for the entire SRB are either the average or summation of simulations from all sub-basins in SRB depending on the hydrologic metric evaluated.

\subsubsection{Evaluation of historical model fitness}

Statistical fit of the daily time series to measured streamflow was evaluated by the Nash Sutcliffe efficiency (NS), Relative
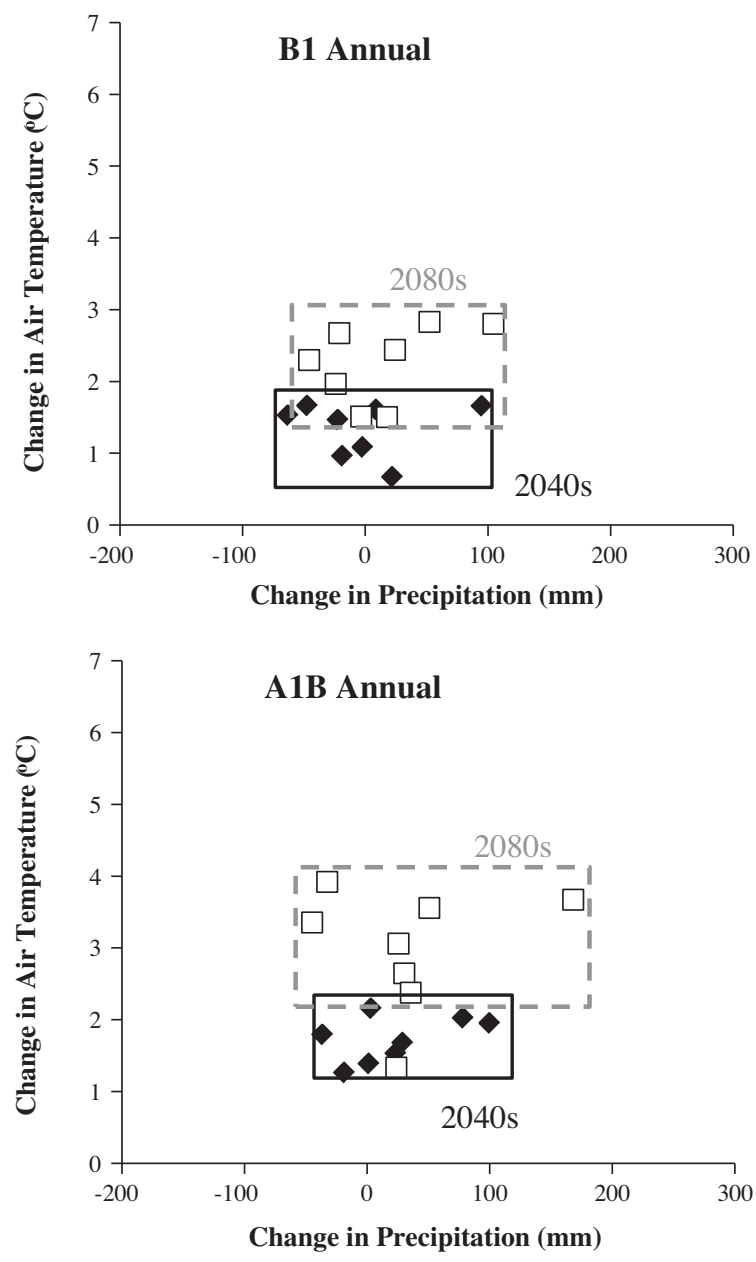

Fig. 2. Average change in air temperature and precipitation for $B 1$ and $A 1 B$ emission scenarios for eight GCM predicting the 2040 and 2080 time periods for the Santiam River basin (SRB). (adapted from Surfleet and Tullos, 2012).
Efficiency (Erel), and percent bias (Pbias) for the three study subbasins NFS, SFS, and TCS as well as the SRB.

Nash-Sutcliffe efficiency (NS) $=\left[\Sigma\left(o_{i}-\overline{0}\right)^{2}-\Sigma\left(o_{i}-S_{i}\right)^{2}\right] / \Sigma\left(o_{i}-\bar{o}\right)^{2}$

Percent bias (Pbias) $=\left[\Sigma s_{i}-\Sigma o_{i}\right] / \Sigma o_{i} \times 100 \%$

Relative Efficiency $($ Erel $)=1-\Sigma\left(\frac{o_{i}-s_{i}}{o_{i}}\right)^{2} / \Sigma\left(\frac{\left(o_{i}-\overline{0}\right)}{\bar{o}}\right)^{2}$

where $O$ is observed flow, $S$ is simulated flow, $n$ is a number of data, and $i$ indicates time step.

Statistical fit to SWE in the North Santiam below Boulder Creek sub-basin was evaluated using the NS statistic. Only the North Fork Santiam below Boulder Creek sub-basin was used for evaluating fit to SWE because it is the only sub-basin entirely within the high elevation, snow-dominated climate of the SRB (Fig. 1); long-term snow measurements were not available for low elevation areas of the SRB. SWE output from GSFLOW is based on an average across the sub-basin modeled.

\subsubsection{Peak daily streamflow, rain-on-snow events, and SWE change}

The $\geqslant 1$-year peak daily flows from the eight GCM projections for the simulated historical, 2040, and 2080 time periods were estimated. The future evaluation time periods of 2040 and 2080 were defined by the water years 2030-2059 and 2070-2099, respectively. For comparison, the water years 1960-2010 of the GCM-forced GSFLOW output were used as the historical period. The return interval of peak daily flows was determined by fitting the annual series of peak daily flows for each time period and sub-basin to a Generalized Extreme Value distribution. The 1, 2, $10,20,50$ and 100-year peak daily flows were calculated for the three measured streamflow locations and SRB and are presented as the ensemble mean of the eight GCMs for the 2.5, 50, and 97.5 percentiles from the model uncertainty assessment.

The percentage of ROS events were calculated for $\geqslant 1$-year return peak flows and $\geqslant 5$-year return peak flows from the 2.5, 50, and 97.5 percentile GSFLOW output for the historical, 2040, and 2080 time periods. The percentage of ROS events was calculated by sub-basin; the average of all sub-basins represents the result for the SRB. The spatial distribution of the percentage of $\geqslant 1$-year return peak daily flows associated with ROS is mapped by quartiles for the SRB sub-basins for each time period. The percentage of $\geqslant 1$ year return peak daily flows associated with ROS quartiles were further represented as contours.

The percent change in 2040 and 2080 SWE from simulated historical output was calculated for each month from the ensemble mean of the $2.5,50$, and 97.5 percentile monthly values. SWE loss was defined as the difference in SWE at start of a precipitation event and SWE at end of a precipitation event. The total predicted SWE loss was calculated as the difference between the median simulated runoff and average rain precipitation from the eight GCMs for only ROS events. Rain precipitation was defined as precipitation on days with a maximum air temperature $>0{ }^{\circ} \mathrm{C}$.

\section{Results}

\subsection{Fit of hydrologic model predictions to historical measurements}

The median of the simulated daily streamflow showed good fit to measured streamflow for NFS, SFS, TCS, and SRB. NS values are greater than 0.7 and Pbias values are less than $10 \%$ for all simulations, with the exception of the SRB with Pbias at 12.6\% (Table 2). The Erel statistic results, which represent fit of the entire time series with fitness sensitivity to low flow events, are greater than 
Table 2

Statistical fit of the median simulated daily streamflow to historical daily streamflow as measured at three study sub-basins and the Santiam River basin (SRB) and fit to snow water equivalent for snow dominated North Santiam below Boulder Creek subbasin (NFS).

\begin{tabular}{llll}
\hline Streamflow & & & \\
\hline USGS gauging station & NS & Pbias (\%) $^{\mathrm{a}}$ & Erel \\
\hline North Santiam below Boulder Crk (NFS) & 0.71 & 12.6 & 0.79 \\
South Santiam at Cascadia (SFS) & 0.75 & 2.7 & 0.67 \\
Thomas Creek (TCS) & 0.75 & 2.0 & 0.99 \\
Santiam R. at Jefferson (SRB) & 0.73 & 7.5 & 0.86 \\
Snow water equivalent (SWE) & & & \\
N Santiam below Boulder Crk & & \\
\end{tabular}

a Percent bias is same for monthly and daily values.

b SWE could only be tested for fit in the snow dominated sub-basin NFS.

0.70 for all but the SFS sub-basin. The simulated SWE output from the NFS study sub-basin showed good fit to measured SWE (NS value of 0.95). These results indicate that the models are representing the important hydrological processes based on historical streamflow.

\subsection{Historical frequency of rain-on-snow events in Santiam River Basin}

Peak daily flows $\geqslant 1$-year return interval have a high frequency of ROS events within the SRB for the 1986-2010 time period (Table 3 ). More than $74 \%$ of peak daily flows $\geqslant 1$-year return interval are associated with ROS events in the three sub-basins evaluated. The highest frequency of ROS events occur in the SFS sub-basin; $83 \%$ of $\geqslant 1$-year events and $100 \%$ of $\geqslant 5$-year events (Table 3 ). The SFS sub-basin has the highest amount of its area, approximately $85 \%$, within the middle elevation zone (350-1100 m), characterized as the transient rain and snow zone. The NFS and TCS sub-basins had slightly lower but similar percentages (Table 3 ). In NFS, with approximately $75 \%$ of its area in the high elevation zone, $80 \%$ of the highest peak flows $\geqslant 5$-year return interval were associated with ROS. The remaining $20 \%$ of the $\geqslant 5$-year return peak daily flows were snowmelt-only events. TCS, with approximately $35 \%$ of its area in the low elevation zone, had $75 \%$ of $\geqslant 1$ year return interval peak daily flows associated with ROS.

\subsection{Predicted frequency of rain-on-snow events in the Santiam River Basin}

The predicted (median) frequency of simulated ROS events for the SRB decreases in the future with the exception of NFS (Fig. 3). The average percentage of peak flows $\geqslant 1$-year and $\geqslant 5$ year return intervals for all sub-basins in the SRB were simulated to be $64-70 \%$ historically and projected to decrease to $25-30 \%$ in 2080 , depending on emission scenario analyzed. Overall the percentage of daily peak flows associated with ROS events for the SRB was predicted to decrease by approximately $1 / 2$ the historical percentage by 2080 . Much greater decreases in frequency of ROSassociated peak flows are predicted for the sub-basins with areas
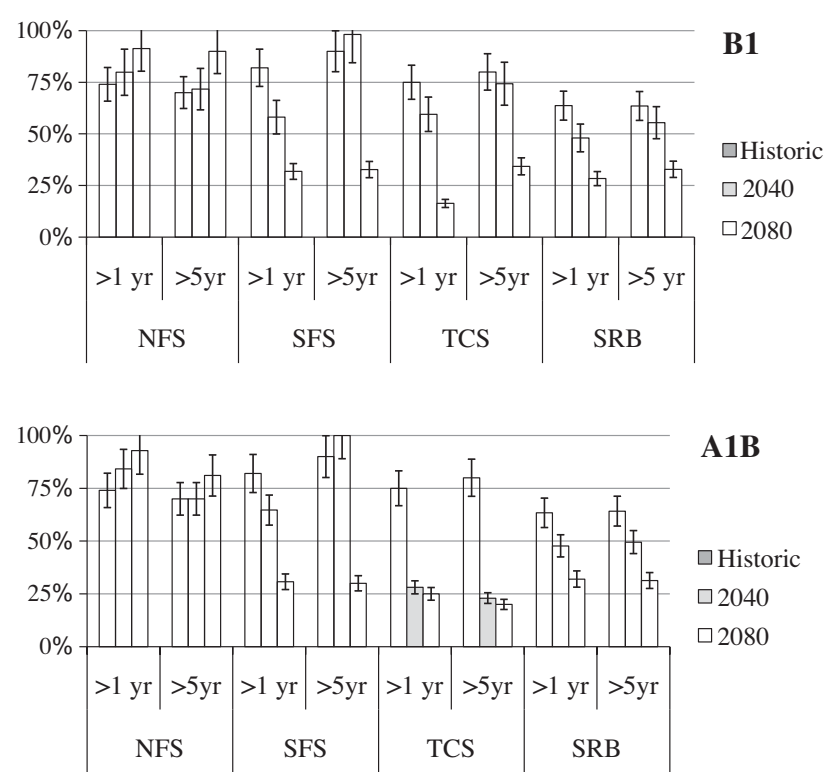

Fig. 3. Percent of peak daily flows $\geqslant 1$ and $\geqslant 5$ year return intervals from median simulated rain-on-snow events for Historical, 2040, and 2080 time periods for North Santiam below Boulder Creek (NFS), South Santiam at Cascadia (SFS), Thomas Creek (TCS), and Santiam River basin (SRB) for (A) B1 and (B) A1B scenarios. Error bars represent the range of percent change between 2.5 and 97.5 percentile output

in the middle elevation zone, SFS and TCS. The NFS sub-basin, the highest elevation sub-basin, has a predicted increase in the frequency of simulated (median) peak daily flows associated with ROS events; the frequency of ROS events were simulated to be $65-70 \%$ historically and to increase to $80-90 \%$ in 2080 (Fig. 2), depending on emission scenario and size of peak flow ( $\geqslant 1$-year and $\geqslant 5$-year return intervals).

The 2.5 and 97.5 percentile values of simulated peak flows generally follow the same trend of change for the median percentage of ROS-associated peak daily flows (Fig. 3). The range of 2.5-97.5 percentile predictions for the NFS overlap for each subsequent time period (Historical, 2040, 2080) demonstrating uncertainty in predicted change. The range of $2.5-97.5$ percentile predictions for the percentage of ROS associated peak daily flows for the SFS, TCS, and SRB in most cases overlap between the historical and 2040 time periods, but with no overlap in predictions between the historical and the 2080 time period. These results indicate that predicted differences are higher than modeling uncertainty for the historical to 2080 comparison but not for the historical to 2040 comparison.

The shift in frequency of ROS-associated peak flows to higher elevations is demonstrated in the spatial representation of ROS frequency (Fig. 4). Contours of percentage of $\geqslant 1$-year return peak daily flows associated with ROS events are shown. The contours were developed spatially, from the percentage of ROS peak daily flows of each sub-basin, based on the sub-basin centroid. The historical spatial trend has the highest frequency of ROS events in the middle elevation zone of the SRB, corresponding to the historical transient

Table 3

Frequency of historical rain on snow events for peak flows $\geqslant 1$ year return interval, based on observed streamflow from 1986 to 2009 for North Santiam below Boulder Creek (NFS) and South Santiam at Casacadia (SFS); from 1986 to 1987 and 2002 to 2010 for Thomas Creek (TCS).

\begin{tabular}{|c|c|c|c|}
\hline River gauge & Elevation range $(\mathrm{m})$ & $\geqslant 1$ Year peak flow events (\%) & $\geqslant 5$ Year peak flow events (\%) \\
\hline North Santiam below Boulder Creek (NFS) & $485-3200$ & 74 & 80 \\
\hline South Santiam at Cascadia (SFS) & $235-1630$ & 83 & 100 \\
\hline Thomas Creek(TCS) & $120-1340$ & 75 & $\mathrm{n} / \mathrm{a}^{\mathrm{a}}$ \\
\hline
\end{tabular}

\footnotetext{
a Period of record for Thomas Creek too short for this calculation.
} 


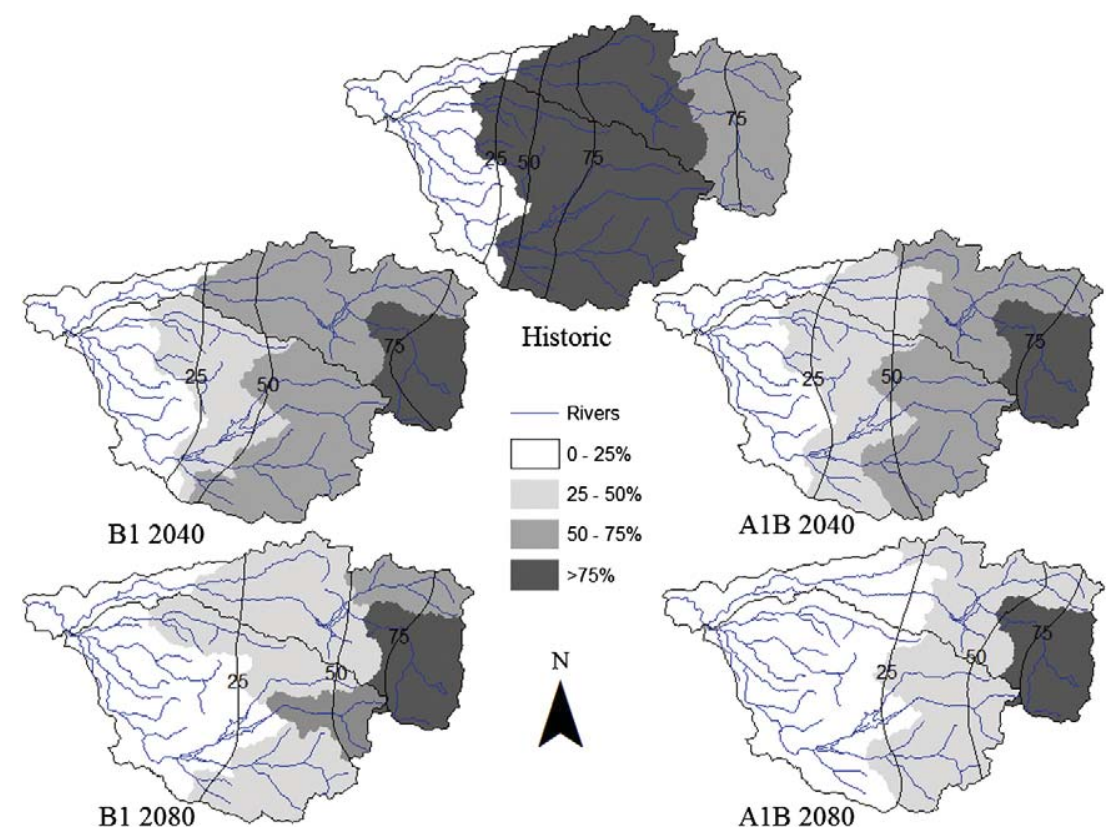

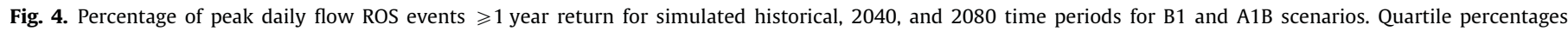
presented by sub-basin; contours developed from sub-basin percentages at the sub-basins' centroids.

rain and snow zone (350-1100 m elevation). The highest elevation sub-basin, NFS, with elevations reaching $3199 \mathrm{~m}$, historically had fewer ROS events than the middle elevation sub-basins due to the cold winter air temperatures and less frequent rain precipitation. In 2040 the frequency of peak flows associated with ROS events decreases (Fig. 3) in the lower and middle elevation zones of the SRB, with the highest percentages of ROS events shifting upward to the high elevation zone of the basin (the NFS sub-basin). In 2080 the greatest decrease in frequency of ROS events occurs in the lower and middle elevation zones. As expected, these changes in the spatial distribution of the frequency of ROS-driven peak flows are greatest for the A1B scenario, the emission scenario with higher projections of greenhouse gas.

\subsection{Frequency of extreme peak daily flow}

Predictions for the simulated (median) peak daily flows for the three study sub-basins indicate that increases in the lower return peak flows events (<10-year return intervals) and decreases or no change in the higher peak flow events ( $\geqslant 10$-year return intervals) (Fig. 5; Table 4) are predicted to occur in the future. Results for the SRB indicate that increases in all peak daily flow return intervals will occur except for the 2080 A1B emission scenarios (Table 4), which has predicted increases in the $<10$-year return interval peak flows events and decreases for the $\geqslant 10$-year return interval peak flows (Fig. 5D; Table 4).

The range of 2.5 and 97.5 percentile peak daily flow predictions (as shown by the error bars in Fig. 5) for the 2040 time period generally encompass the historical values for the three study sub-basins and SRB. The range of 2.5 and 97.5 percentile peak daily flow predictions for the 2080 time period generally do not encompasses the historical values for all sub-basins and SRB, with the exception where the peak flow frequency distribution converge between the 5 and 20 year event, depending on sub-basin. The largest variation from the median peak daily flow predictions occurs for the higher peak flow events ( $\geqslant 10$-year return intervals) for the NFS sub-basin for both 2040 and 2080 (Fig. 5A). For the NFS higher peak flow events, the variation is greatest for the 2.5 percentile predictions, demonstrating that the more extreme peak flows could be reduced lower than the median predictions in the future.

Individually, the responses to future warming vary by a basin's location and elevation. For the NFS, predominately in the high elevation zone, the median peak daily flow events $\geqslant 10$-year return interval were predicted to be $7 \%$ and $18 \%$ less frequent than historically for A1B and B1 emission scenarios in 2080, respectively (Fig. 5A; Table 4). Conversely, the NFS median peak flow events $<10$-year return interval increase in magnitude. For example, the 1-year event was predicted to increase $17 \%$ and $41 \%$ for the B1 and A1B emission scenarios in 2080, respectively (Table 4). A similar yet smaller decrease was predicted for peak flow events $\geqslant 10$-year return interval for the B1 and A1B scenarios for SFS, predominately in the middle elevation zone; simulations projected a 9\% and 10\% decrease in median peak flow magnitude in 2080 for SFS (Fig. 5B; Table 4). Median peak flow events of $<10$-year return interval for SFS are predicted to become more frequent by $16 \%$ and $21 \%$ for the B1 and A1B emission scenarios, respectively (Table 4). Only a small decrease in the median peak flows $\geqslant 10$-year return interval was predicted in 2080 for TCS; with areas in the low and middle elevation zones. However, median peak daily flows $<10-$ year return interval for TCS are predicted to increase; The median 1-year return events for B1 and A1B scenarios increase $16 \%$ and $26 \%$ respectively in 2080 for TCS (Fig. 4C; Table 2). The SRB median peak flow events $\geqslant 10$-year return interval are predicted to increase slightly for 2040 but decrease in the 2080 A1B scenario. The median 1-year return events for SRB in B1 and A1B scenarios are projected to increase by $16 \%$ and $27 \%$ respectively in 2080 (Fig. 5D; Table 4).

\subsection{Changes in snow water equivalent (SWE) and precipitation type in future}

SWE was predicted to decrease $50-100 \%$ across the SRB for the 2040 and 2080 time periods depending on emission scenario (Fig. 6). With warmer air temperatures in the future, less snow is predicted to occur, lowering SWE and forcing the transient rain and snow zone to higher elevations (Fig. 4). The greatest loss of SWE occurs in the TCS sub-basin, the lowest-elevation sub-basin 


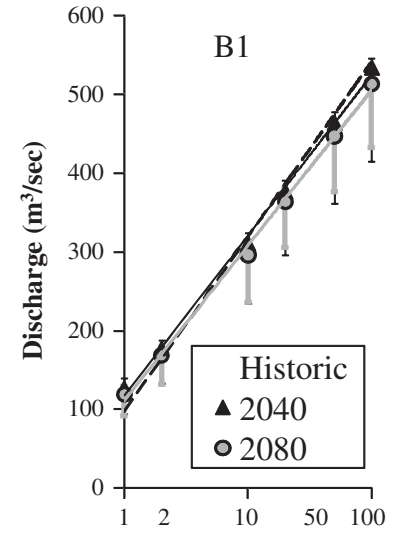

(A) NFS

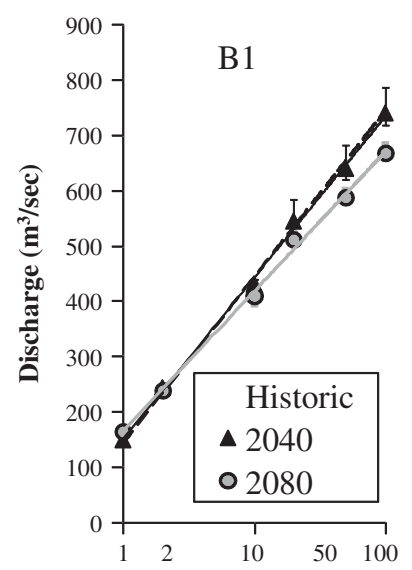

(B) SFS
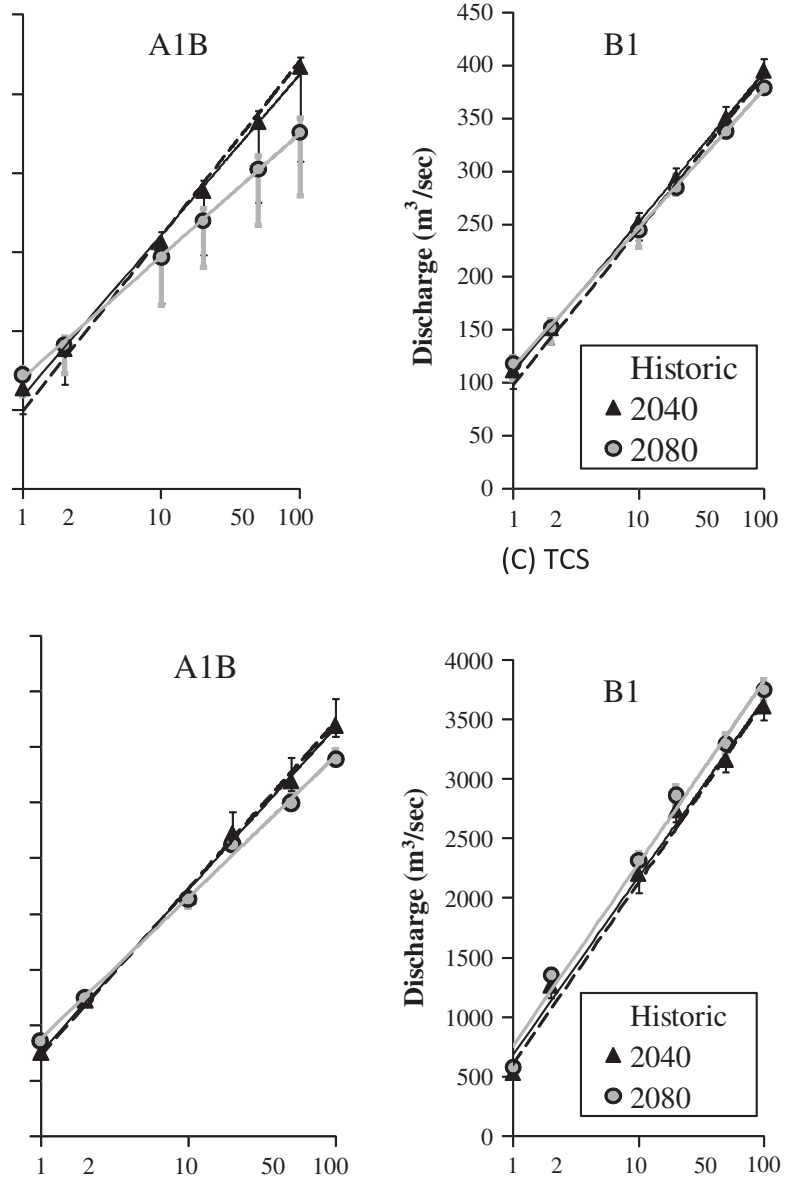

(D) SRB

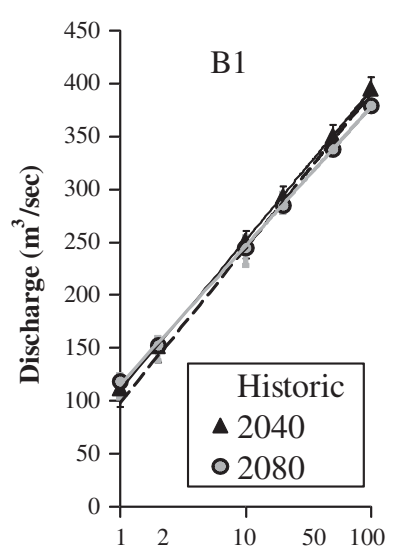

(C) TCS
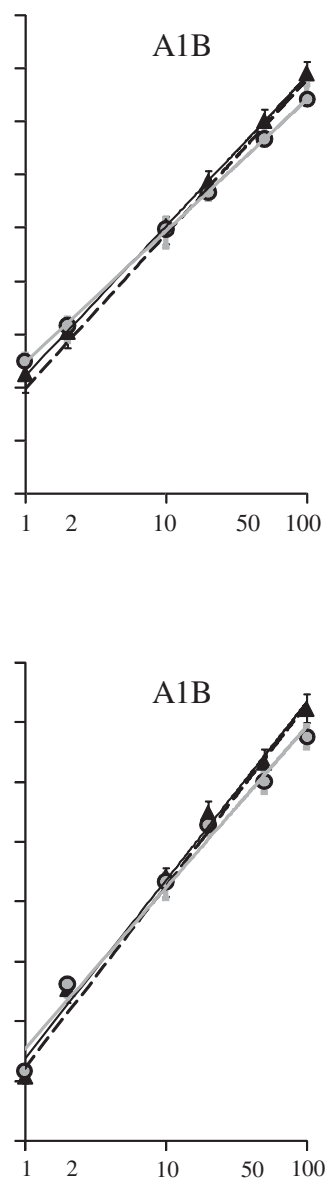

Fig. 5. Comparison of median simulated Historical, 2040 and 2080 predicted extreme value peak flows of 1, 2, 10, 20, 50 , and 100 year return interval (A) North Santiam below Boulder Creek (NFS), (B) South Santiam at Cascadia (SFS), (C) Thomas Creek (TCS), and (D) Santiam River basin (SRB). X axis is return interval (years); dashed line is Historical relationship; thin black line is 2040 relationship; gray dash line is 2080 relationship. Error bars represent represent 2.5 and 97.5 percentile predictions from range of GSFLOW output due to GCM and hydrologic model uncertainty.

Table 4

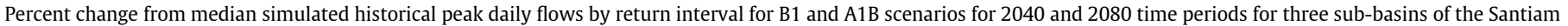
River and Santiam River basin; North Santiam below Boulder Creek (NFS), South Santiam at Cascadia (SFS), Thomas Creek (TCS) and Santiam River basin (SRB) .

\begin{tabular}{|c|c|c|c|c|c|c|c|c|c|c|c|c|c|c|c|c|}
\hline \multirow{3}{*}{$\begin{array}{l}\text { Return } \\
\text { (year) }\end{array}$} & \multicolumn{8}{|c|}{2040} & \multicolumn{8}{|l|}{2080} \\
\hline & \multicolumn{4}{|l|}{ B1 } & \multicolumn{4}{|l|}{ A1B } & \multicolumn{4}{|l|}{$\mathrm{B} 1$} & \multicolumn{4}{|l|}{$\mathrm{A} 1 \mathrm{~B}$} \\
\hline & $\begin{array}{l}\text { NFS } \\
(\%)\end{array}$ & $\begin{array}{l}\text { SFS } \\
(\%)\end{array}$ & $\begin{array}{l}\text { TCS } \\
(\%)\end{array}$ & $\begin{array}{l}\text { SRB } \\
(\%)\end{array}$ & $\begin{array}{l}\text { NFS } \\
(\%)\end{array}$ & $\begin{array}{l}\text { SFS } \\
(\%)\end{array}$ & $\begin{array}{l}\text { TCS } \\
(\%)\end{array}$ & $\begin{array}{l}\text { SRB } \\
(\%)\end{array}$ & $\begin{array}{l}\text { NFS } \\
(\%)\end{array}$ & $\begin{array}{l}\text { SFS } \\
(\%)\end{array}$ & $\begin{array}{l}\text { TCS } \\
(\%)\end{array}$ & $\begin{array}{l}\text { SRB } \\
(\%)\end{array}$ & $\begin{array}{l}\text { NFS } \\
(\%)\end{array}$ & $\begin{array}{l}\text { SFS } \\
(\%)\end{array}$ & $\begin{array}{l}\text { TCS } \\
(\%)\end{array}$ & $\begin{array}{l}\text { SRB } \\
(\%)\end{array}$ \\
\hline 1 & 24 & 6 & 6 & 16 & 24 & 6 & 14 & 16 & 17 & 16 & 16 & 27 & 41 & 21 & 26 & 27 \\
\hline 2 & 6 & 3 & 3 & 7 & 6 & 3 & 7 & 7 & 2 & 1 & 1 & 14 & 10 & 6 & 11 & 10 \\
\hline 10 & -1 & -1 & -1 & 3 & -1 & -1 & 3 & 3 & -6 & -6 & -6 & 8 & -7 & -2 & 2 & 1 \\
\hline 20 & -1 & -1 & -1 & 2 & -1 & -1 & 2 & 2 & -4 & -7 & -7 & 6 & -11 & -5 & -1 & -2 \\
\hline 50 & -2 & -1 & -1 & 1 & -2 & -1 & 2 & 1 & -6 & -9 & -9 & 5 & -15 & -7 & -3 & -4 \\
\hline 100 & -3 & -1 & -1 & 1 & -3 & -1 & 1 & 1 & -7 & -10 & -10 & 4 & -18 & -9 & -5 & -6 \\
\hline
\end{tabular}

in the study. TCS was also the sub-basin with the greatest amount of uncertainty in SWE change predictions during winter months (Fig. 6). The predicted decrease in SWE for TCS by the 2.5 and 97.5 percentile values differed from the median predicted change by $5 \%$ to $20 \%$. NFS predictions of early summer for the B1 scenario also showed high uncertainty. No change in SWE was predicted in the summer months for SFS and TCS because these sub-basins do not have snow on the ground during summer (June-October). The NFS and the subsequent SRB prediction do retain some patches of snow in the highest elevations during summer. High-elevation snow dynamics during the summer months are characterized by high SWE loss but also historically low snow amounts.
The total rain and snowmelt in ROS events generally decreases into the future for the low and middle elevation sub-basins TCS and SFS (Fig. 7). This is due to the predicted lower percentage of peak flows associated with ROS in the future. The total rain precipitation in ROS events in NFS, the highest elevation sub-basin, increases in the future, yet total snowmelt shows little change. The snowmelt relative to increased rain precipitation decreases the percentage of SWE in ROS events in the future for NFS (Table 5) while TCS and SFS generally show higher percentages of SWE in ROS events in the future. TCS and SFS were predicted to have a lower percentage of peak flows associated with ROS events (Fig. 3) and less SWE in the future (Fig. 6). 

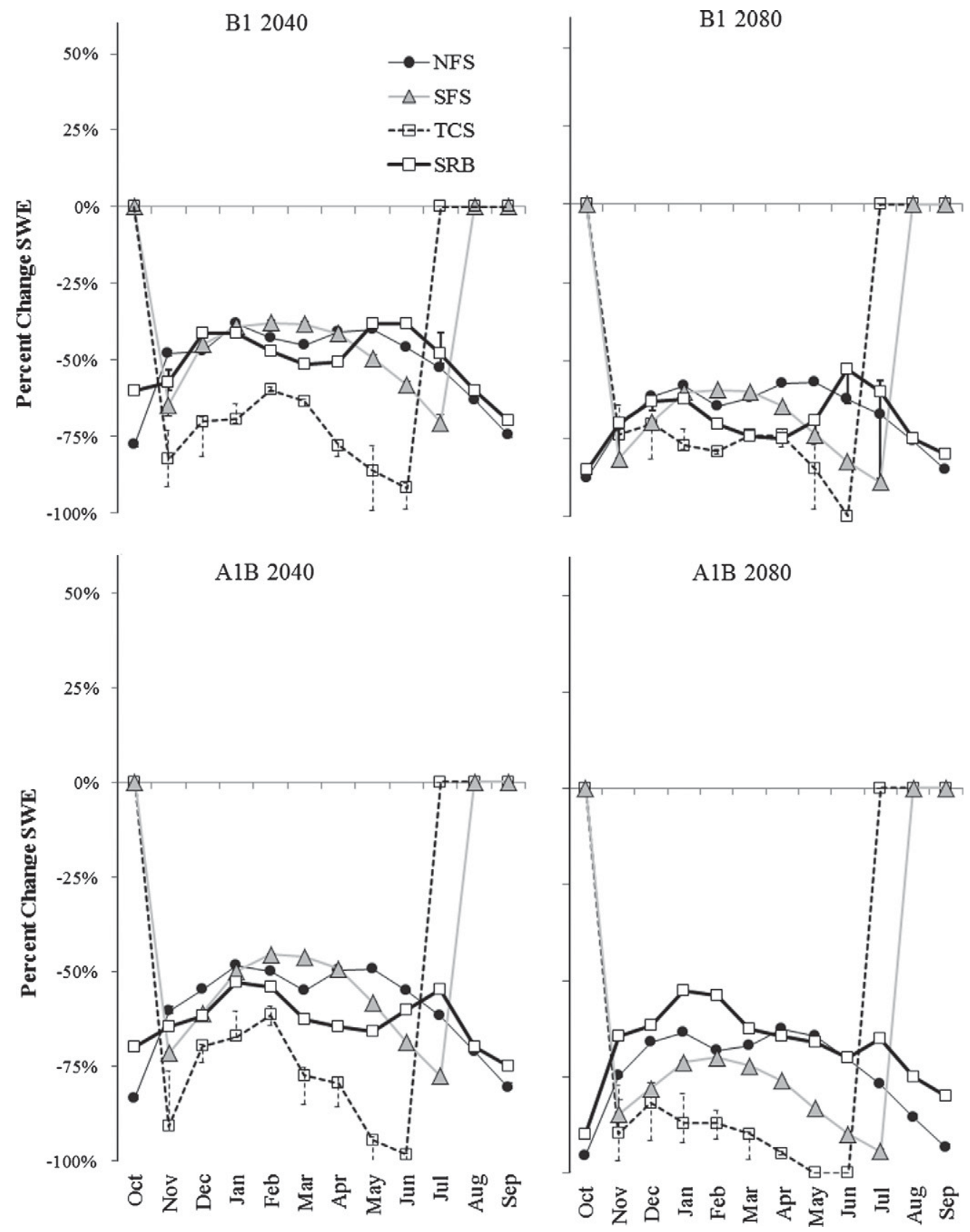

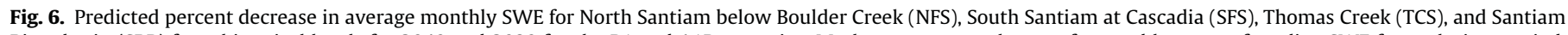

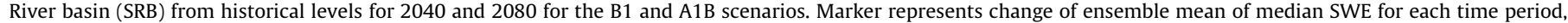
lower error bar represents change of ensemble mean of 2.5 percentile SWE, and upper error bar represents change of ensemble mean of 97.5 percentile SWE.

\section{Discussion}

ROS events play a critical role in generated floods in the SRB. A warming climate is projected to modify this role of ROS events across elevation and event magnitude.

\subsection{Rain-on-snow (ROS) and floods}

Historically, the largest peak flows, shown in this study as $\geqslant 5$ year return interval, have a high frequency of ROS events (80-100\%) (Table 3). The frequency of ROS events associated peak flows $\geqslant 1$-year return interval for the SRB was $61 \%$. The high frequency of ROS events associated with flooding is consistent with other studies within mountainous watersheds in a temperate climate (e.g. Kattelman et al., 1991; McCabe et al., 2007; Sui and Koehler, 2001). The transient rain and snow zone found in mountainous areas of temperate climates, where air temperature and subsequent precipitation type vary during winter, promotes ROS occurrence. Indeed, the flood of record for the SRB (February 1996) was a ROS event, resulting from heavy rain due to warm tropical air flow and moisture following high snow accumulations (Marks et al., 1998).

\subsection{Future ROS events and flooding}

Future hydrology of the Northwest United States has been predicted to change due to warmer air temperatures, resulting in decreased snow precipitation and increased rain precipitation (e.g. 


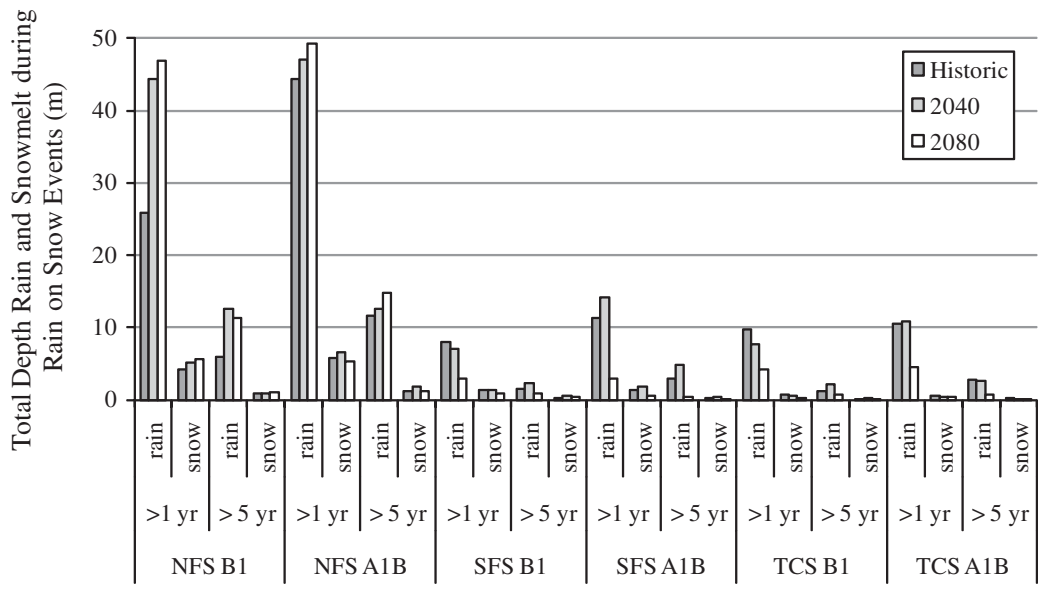

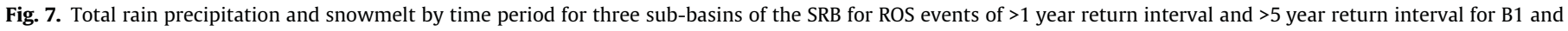

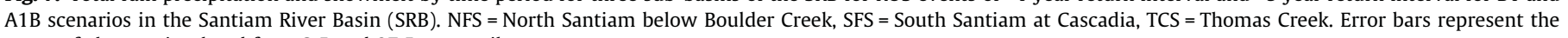
range of change simulated from 2.5 and 97.5 percentile output.

Table 5

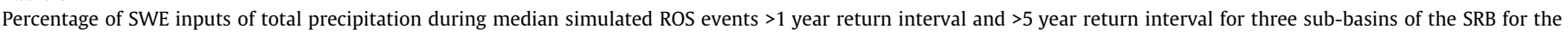
historical, 2040 and 2080 time periods for B1 and A1B scenarios.

\begin{tabular}{|c|c|c|c|c|c|c|}
\hline \multirow[t]{2}{*}{ Time period } & \multicolumn{2}{|c|}{ North Santiam below Boulder Creek (NFS) } & \multicolumn{2}{|c|}{ South Santiam at Cascadia (SFS) } & \multicolumn{2}{|c|}{ Thomas Creek (TCS) } \\
\hline & $>1$ year event $(\%)$ & >5 year event $(\%)$ & $>1$ year event $(\%)$ & $>5$ year event $(\%)$ & $>1$ year event $(\%)$ & $>5$ year event $(\%)$ \\
\hline \multicolumn{7}{|l|}{ B1 scenario } \\
\hline Historic & 16 & 15 & 17 & 14 & 7 & 11 \\
\hline 2040 & 12 & 7 & 19 & 25 & 8 & 11 \\
\hline 2080 & 12 & 9 & 31 & 47 & 6 & 11 \\
\hline \multicolumn{7}{|l|}{ A1B scenario } \\
\hline Historic & 13 & 10 & 13 & 11 & 6 & 7 \\
\hline 2040 & 14 & 15 & 13 & 9 & 4 & 6 \\
\hline 2080 & 11 & 8 & 17 & 32 & 10 & 8 \\
\hline
\end{tabular}

Eckhardt and Ulbrich, 2003; Gellens and Roulin, 1998; Hamlet et al., 2010; Surfleet and Tullos, 2012; Yang et al., 2002). The results suggest that the trend of change is likely to be nuanced, varying with elevation and event magnitude. The frequency of ROS events for peak flows $\geqslant 1$-year return interval and amount of SWE available for ROS events are predicted to decrease in the SRB (Figs. 3-6), with the exception of the high elevation NFS sub-basin. The frequency of ROS events in the NFS sub-basin increases in the future, but a substantial decrease in SWE simultaneously occurs (Fig. 6). The decrease in the percentage of SWE for the SRB was shown to be relatively consistent across the SRB by time period and emission scenario with the exception of TCS, the low elevation sub-basin, and summer months. With the predicted increase in air temperature due to climate change (Fig. 2), the transient zone will shift to higher elevations (Fig. 4). In the historical time period, the highest frequency of ROS events occurred in the middle elevation zone of the SRB (Table 3). In the 2040 simulation period, the highest frequency of ROS events shifts to higher elevation sub-basins. By 2080 only the NFS sub-basin has ROS event frequencies in the $75-100 \%$ quartile of the $\geqslant 1$-year return interval, the frequency of ROS events that is consistent with the historical mid-elevation transient zone (Fig. 4).

The change in the size and frequency of peak flows for the NFS, SFS, TCS, and SRB illustrate that the greatest increase in peak flow will occur for the 1-year event (Fig. 5; Table 4). The historical 1 -year event, on average, will be more frequent than once every year. For the SRB, a $27 \%$ increase in the historical 1-year event (Table 4) translates to an increased frequency of occurrence; the same size peak flow will be a 0.75-year return interval by 2080 for both B1 and A1B scenarios. The historical 100-year peak flow for SRB is predicted to decrease in frequency in the future; the same peak flow would be classified a 120-year event for the 2080 A1B scenario. Increases in the predicted peak flow magnitude and frequency generally reverse to decreases in predicted peak flow magnitude and frequency after the 5-20-year return intervals, depending on location in SRB (Fig. 5). The general result is a projected increase in frequencies of the smaller floods, but a projected decrease or no change in the largest floods in the future. However, this trend is predominately occurring in the middle and high elevation areas, as represented by the TCS, SFS and NFS sub-basins (Fig. 5). The greatest amount of predicted decrease in the highest peak flow events occurs at NFS, the highest elevation sub-basin. The low elevation areas, which are included in averaged SRB values, influence the projection of a smaller decrease to a slight increase in size and frequency for the higher flood events ( $\geqslant 10$-year return interval; Fig. 5) in the SRB.

Several studies of hydrologic response to climate change predict increases in winter flooding in the future due to climate change (e.g. Hamlet et al., 2010; Mote et al., 2003). The projected shift from snow precipitation to rain precipitation, and the subsequent reduction in storage of snow water, will result in increases in quickflow runoff during winter storms and decreases in spring snowmelt runoff. In this study a similar trend is projected for the most frequent flood events (1-10-year return interval peak flows). However, our results also project a decrease in the least frequent extreme flood events ( $\geqslant 10$-year return interval peak flows) for the middle and high elevation zones, particularly for the high elevation zone (NFS sub-basin, Fig. 5).

The projected decrease in SWE and increase in rain precipitation will result in a decrease in frequency of peak flows associated with ROS for all but the NFS sub-basin. The NFS sub-basin, which historically had much of its area above the transient rain and snow 
zone, is predicted to be within the transient zone in the future. Yet the greatest decrease in size of the largest peak flow events is projected for the NFS sub-basin. A reduction of $18 \%$ in the median $100-$ year return interval was predicted for the $\mathrm{A} 1 \mathrm{~B}$ emission scenario in 2080 (Fig. 5; Table 4). The NFS is predicted to experience increased frequency in peak flows associated with ROS $\geqslant 1$ and $\geqslant 5$-year return intervals. These peak flow events are also predicted to be characterized by increased rain precipitation but little change in total snow inputs for ROS events (Fig. 7). Increased frequency in ROS events, increased rain precipitation but little change in snowmelt in ROS events will result in less snowmelt in individual ROS events. The reduction in snow associated with ROS events in NFS, even though ROS are predicted to be more frequent, could explain the predicted decrease in the magnitude of the highest peak flows $(\geqslant 10$-year events).

A similar result was presented in a study of changes to floodmagnitude associated with climate change in southern British Columbia (Loukas et al., 2002). In one watershed, whose hydrology was driven primarily by autumn rain with winter ROS, the peak flows were predicted to increase in the autumn due to increased rain precipitation and remain unchanged in winter creating an overall increase of the frequency of peak flows due to climate change (Loukas et al., 2002). However, in another predominately snow-dominated watershed where the highest peak flows occur due to rain combined with spring snowmelt, a predicted decrease in snowpack will lower the frequency and magnitude of the ROS events due to climate change. In the southern British Columbia study (Loukas et al., 2002), an increase in ROS events was predicted in high elevation areas due to the shift of transient snowpack to higher elevations, while a decrease in the magnitude of the ROS peak flows was observed due to the reduction in accumulated snowpack.

\subsection{Uncertainty in predictions of future ROS events}

The approach to future predictions of hydrologic response to climate change requires the use of simulated future climate (GCMs) and hydrologic models. The use of GCMs represent several levels of uncertainty, from lack of knowledge regarding future emissions of greenhouse gases, to differing responses of GCMs to greenhouse gas emission scenarios, to uncertainty added by the downscaling used to translate landscape-level GCMs to local scales (Maurer, 2007). As a result, the range of air temperature and precipitation changes varies greatly among the eight GCMs used in this study (Fig. 2). The GCM uncertainty generally increases between 2040 and 2080 predictions (Fig. 2). In the study of uncertainty of hydrologic response to climate change in the SRB, it was found that GCM uncertainty represented the greatest amount of uncertainty in predictions (Surfleet and Tullos, 2012). Further, land use change and the climate-landscape feedbacks are typically not included in GCM simulations representing additional uncertainty (e.g. Feddema et al., 2005; Merz et al. 2011; Mote et al., 2003). The simulation of hydrology presents uncertainties associated with rainfall-runoff models due to both model structure and parameter uncertainties (e.g. Beven and Binley, 1992; Beven, 1993; Brazier et al., 2000).

To address uncertainty in our ROS predictions, eight GCMs, with varying forcing data predictions (Fig. 2), were cascaded through a hydrologic model uncertainty assessment. Ultimately the model output was a distribution of values. The comparisons of percent of peak daily flows with ROS (Fig. 3), representations of extreme value peak flows (Fig. 5), and SWE predictions (Fig. 6) considered this entire range of model output. With the exception of TCS, the percent change in SWE was predicted to be the same across the distribution of model output (Fig. 6). Similarly future peak flow values were predicted to be similar for the range of model output with the exception of NFS (Fig. 5). The TCS and NFS uncertainties stem primarily from the parameterization of the hydrologic model and the complexity of the hydrogeology in these sub-basins (Surfleet and Tullos, 2012). These results highlight how and why uncertainties in 2080 projections are higher than for the 2040 projections.

\section{Conclusions}

In the Santiam River basin, peak daily flows $\geqslant 1$-year return are shown to be frequently driven by ROS events. Historically the greatest frequency of peak daily flows $\geqslant 1$-year return interval associated with ROS events occur in the transient zone of the basin (350-1100 $\mathrm{m}$ in elevation). Future predictions of hydrologic response in SRB due to climate change indicate an overall decrease in frequency of ROS events, due to less snow available for ROS events. The exception was the highest-elevation NFS sub-basin, which had a predicted increase in ROS events and illustrates how the transient zone is likely to shift upward in elevation in the future. However, though ROS events were predicted to be more frequent in the high elevation NFS sub-basin, snow precipitation will decrease, thereby decreasing the size of the largest ROS events in the future. The predicted increase in rain precipitation during winter will increase the frequency of peak flow events $<5-10$-year return interval in the SRB. Decreases in snow in ROS events will create either little change or a decrease in the frequency of the largest peak flow events ( $\geqslant 10$-year events). Our results also demonstrate how the response of individual basins will vary based on position relative to the transition rain and snow zone. The largest decrease in the largest peak flow events will occur in the highest elevation areas, though the frequency of ROS are predicted to increase in these high elevation regions. The projected changes in flood frequencies illustrate the importance of re-evaluating the adequacy of water resources infrastructure and design approaches in meeting objectives (e.g. flood control, water supply, etc.), particularly under conditions where high frequency events become more frequent.

\section{Acknowledgements}

This material is based upon work supported by the National Science Foundation under Grant No. 0846360. Any opinions, findings, and conclusions or recommendations expressed in this material are those of the authors and do not necessarily reflect the views of the National Science Foundation. The research was also funded in part by the National Science Foundation through TeraGrid resources provided by Purdue University under grant number TGECS100006. We specifically acknowledge the assistance of Phil Cheeseman at Purdue University. We thank Heejun Chang and IlWon Jung of Portland State University for their contributions of climate data, spatial data, and apriori parameter values from their use of PRMS for the Williamette River basin. We received considerable assistance from R. Steven Regan and Rich Niswonger, of the United States Geological Survey, on the implementation and use of GSFLOW. Jasper Vrugt of University of California Irvine provided advice and computer programs for implementation of the DREAM analysis.

\section{References}

Berris, S.N., Harr, R.D., 1987. Comparative snow accumulation and melt during rainfall in forested and clear-cut plots in the Western Cascades of Oregon. Water Resources Research 23 (1), 135-142.

Beven, K., 1993. Prophecy, reality and uncertainty in distributed hydrological modeling. Adv. Water Resour. 16, 41-51.

Beven, K., Binley, A., 1992. The future of distributed models: model calibration and uncertainty prediction. Hydrol. Process. 6, 279-298. 
Brazier, R., Beven, K., Freer, J., Rowan, J., 2000. Equifinality and uncertainty in physically based soil erosion models: application of the GLUE methodology to WEPP-the Water Erosion Prediction Project-for sites in the UK and USA. Earth Surf. Process. Landforms 25, 825-845.

Collins, W., Bitz, C., Blackmon, M., Bonan, G., Bretherton, C., Carton, J., Chang, P. Doney, S., Hack, J., Henderson, T., Kiehl, J., Large, W., McKenna, D., Santer, B. Smith, R., 2006. The community climate system model version 3 (CCSM3). J. Climate 19, 2122-2143.

Eckhardt, K., Ulbrich, U., 2003. Potential impacts of climate change on groundwater recharge and streamflow in a central European low mountain range. J. Hydrol. 284 (1-4), 244-252.

Feddema, J., Oleson, K., Bonan, G., Mearns, L., Buja, L., Meehl, G., Washington, M., 2005. The importance of land-cover change in simulating future climates. Science 310 (5754), 1674-1678. http://dx.doi.org/10.1126/science.1118160.

Ferguson, S., 2000. The spatial and temporal variability of rain-on-snow. In: Proceedings of the International Snow Science Workshop, 1-6 October 2000, Big Sky Montana, American Avalanche Assoc. pp. 178-183.

Gellens, D., Roulin, E., 1998. Streamflow response of Belgian catchments to IPCC climate change scenarios. J. Hydrol. 210 (1-4), 242-258.

Gordon, C., Cooper, C., Senior, C., Banks, H., Gregory, J., Johns, T., Mitchell, J., Wood R., 2000. The simulation of SST, sea ice extents and ocean heat transports in version of the Hadley Centre coupled model without flux adjustments. Climate Dynam. 16, 147-168.

Hamlet, A.F., Carrasco, P., Deems, J., Elsner, M.M., Kamstra, T., Lee, C., Lee, S.Y Mauger, G., Salathe, E.P., Tohver, I., Whitely Binder, L., 2010. Final Project Report for the Columbia Basin Climate Change Scenarios Project. <http:// www.hydro.washington.edu/2860/report/>.

Harbaugh, A.W., 2005. MODFLOW-2005, The U.S. Geological Survey Modular Ground-Water Model-the Ground-Water Flow Process: U.S. Geological Survey Techniques and Methods 6-A16, Variously Paginated.

Inter-governmental Panel on Climate Change (IPCC), 2007. Climate Change 2007: The Scientific Basis. IPCC Contribution of Working Group I to the Fourth Assessment Report of the Intergovernmental Panel on Climate Change. Cambridge University Press, Cambridge.

Jungclaus, J.H., Botzet, M., Haak, H., Keenlyside, N., Luo, J., Latif, M., Marotzke, J. Mikolajewicz, U., Roeckner, E., 2006. Ocean circulation and tropica variability in the coupled model ECHAM5/MPI-OM. J. Climate 19, 3952 3972.

K-1 model developers, 2004. K-1 coupled model (MIROC) description. In: Hasumi, H., Emori, S. (Eds.), K-1 technical report 1: Center for Climate System Research University of Tokyo. <http://www.ccsr.u-tykyo.ac.jp/kyosei/hasumi/MIROC/ tech-repo.pdf>. 34pp.

Kattelman, R., Berg, N., McGurk, B., 1991. A history of rain-on-snow floods in the Sierra Nevada. In: Proceedings of the Western Snow Conference, Juneau, Alaska. <http://www.westernsnowconference.org/proceedings/1991.htm> (accessed October 2011)

Leavesley, G.H., Lichty, R.W., Troutman, B.M., Saindon, L.G., 1983. PrecipitationRunoff Modeling System-User's Manual. U.S. Geological Survey WaterResources Investigations Report 83-4238, 207p.

Loukas, A., Vasiliades, L., Dalezios, N.R., 2002. Potential climate change impacts on flood producing mechanisms in southern Bristish Columbia, Canada using the CGCMA1 simulation results. J. Hydrol. 259, 163-188.

McFarland W., 1983. A description of aquifer units in Western Oregon: US Geological Survey Open-File Report 82-165, 35 p.

Marks, D., Kimball, K., Tingey, D., Link, T., 1998. The sensitivity of snowmelt processes to climate conditions and forest cover during rain-on-snow: a case study of the 1996 Pacific Northwest flood. Hydrol. Process. 12, 1569-1587.

Markstrom S, Niswonger R, Regan R, Prudic D, Barlow, P., 2008. GSFLOW-Coupled Ground-water and Surface-water FLOW model based on the integration of the Precipitation-Runoff Modeling System (PRMS) and the Modular Ground-Wate Flow Model (MODFLOW-2005): U.S. Geological Survey Techniques and Methods 6-D1, 240 p.

Marti, O., Bracommot, P., Bellier, J., Benshila, R., Bony, S., Brockmann, P., Cadulle, P. Caubel, A. Denvil, S., Dufresne, J., Fairhead, L., Filiberti, M., Hourdin, F., Krinner, G., Levy, C., Musat, I., Talandier, C., 2005. The new IPSL climate system model: IPSL-CM4. Institut Poerre Simon Laplace des Sciences del'Environnement Global. <http://www.dods.ipsl.jussieu.fr/omamce/IPSLCM4/>.
Maurer, E., 2007. Uncertainty in hydrologic impacts of climate change in the Sierra Nevada, California, under two emissions scenarios. Clim. Change 82, 309-325.

McCabe, G.J., Clark, M.P., Hay, L.E., 2007. Rain-on-snow events in the western United States. Bull. Am. Met. Soc. 88 (3), 319-328. http://dx.doi.org/10.1175/BAMS-883-319.

Merz, R., Parajka, J., Bloschl, G., 2011. Time stability of catchment model parameters: implications for climate impact analyses. Water Resour. Res. 47, $1-17$.

Middelkoop, H., Daamen, K., Gellens, D., Grabs, W., Kwadijk, J.C.J., Lang, H., Parmet B.W.A.H., Schadler, B., Schulla, J., Wilke, K., 2001. Impact of climate change on hydrological regimes and water resources management in the Rhine basin. Clim. Change 49, 105-128.

Min, S.K., Legutke, S., Hense, A., Kwon, W.T., 2005. Internal variability in a 1000 -year control simulation with the coupled climate model ECHO-G. Part I. Near-surface temperature, precipitation and sea level pressure. Tellus 57A, 605-621.

Mote, P., Parson, E., Hamlet, A., Ideker, K., Keeton, W., Lettenmaier, D., Mantua, N. Miles, E., Peterson, D., Peterson, D., Slaughter, R., Snover, A., 2003. Preparing for climate change: the water, salmon, and forests of the Pacific Northwest. Clim. Change 61, 45-88.

Natural Resources Conversation Service (NRCS), 1986. General soil map, state of Oregon: Portland, Oregon, Natural Resource Conservation Service, scale1: 1000,000 .

NRCS, 2007. Hydrologic soil groups. US Dept. of Agriculture National Engineering Handbook, Part 630 Hydrology. <http://www.directives.sc.egov.usda.gov/ OpenNonWebContent.aspx?content=17757.wba> 14p (Chapter 7)

NRCS, 2011. United States Dept. of Agriculture Natural Resources Conservation Service Snow Telemetry (SNOTEL) Sites. <http://www.wcc.nrcs.usda.gov/ snotel/Oregon/oregon.html>.

Oregon Climate Service, 2010. PRISM map of annual precipitation of the United States. <http://www.ocs.oregonstate.edu/> (Downloaded September 2011).

Sui, J., Koehler, G., 2001. Rain-on-snow induced flood events in southern Germany. J. Hydrol. 252 (1-4), 205-220.

Surfleet, C., Tullos, D., 2012. Uncertainty assessment of hydrologic response to climate change for the Santiam River, Oregon. Hydrol. Proc. http://dx.doi.org 10.1002/hyp. 9485, $16 \mathrm{p}$

Surfleet, C., Tullos, D., Chang, H., Jung, I., 2012. Rainfall runoff modeling efforts for climate change assessment and decision making in the Pacific Northwest. J. Hydrol., 233-248, http://dx.doi.org/10.1016/j.jhydrol.2012.07.012.

Tague, C., Grant, G., Farrell, M., Choate, J., Jefferson, A., 2008. Deep groundwater mediates streamflow response to climate warming in the Oregon Cascades. Clim. Change 86, 189-210.

Terray, L., Valcke, S., Piacentini, A., 1998. Oasis 2.2 Ocean Atmosphere Sea Ice Soil, User's Guide and Reference Manual, Technical Report TR/CMGC/98-05, CERFACS, Toulouse, France.

United States Dept. of Agriculture (USDA), 2011. USDA Natural Resources Conservation Service Oregon SNOTEL Sites. <http://www.wcc.nrcs.usda.gov/ snotel/Oregon/oregon.html> (accessed September, 2011).

US Geological Survey (USGS) Seamless, 2009. National Map Seamless Server. <http://www.seamless.usgs.gov/index.php> (Accessed 10.12.09).

USGS, 2011. United States Geologic Survey surface water daily statistics. <http:/ www.waterdata.usgs.gov/nwis/sw> (accessed September, 2011).

Vrugt, J.A., terBraak, C.J.F., Diks, C.G.H., Higdon, D., Robinson, B.A., Hyman, J.M., 2009. Accelerating Markov chain Monte Carlo simulation by differential evolution with self-adaptive randomized subspace sampling. Int. J. Nonlinear Sci. Numer. Simul. 10 (3), 273-290.

Washington, W., Weatherly, J., Meehl, G., Semtner, A., Bettge, T., Craig, A., Strand, W., Arblaster, J., Wayland, V., James, R., Zhang, Y., 2000. Parallel climate mode (PCM) control and transient simulations. Clim. Dynam. 16, 755-774.

Wood, A.W., Leung, L.R., Sridhar, V., Lettenmaier, D.P., 2004. Hydrologic implications of dynamical and statistical approaches to downscaling climate model outputs. Clim. Change 62, 189-216.

Yang, D., Kane, D.L., Hinzman, L.D., Zhang, X., Zhang, T., Ye, H., 2002. Siberian Lena River hydrologic regime and recent change. J. Geol Res. 107 (D23), 4694, doi 10.1029/2002JD002542. 10p.

Ye, H., Yang, D., Robinson, D., 2008. Winter rain on snow and its association with air temperature in northern Eurasia. Hydrol. Proc. 22, 2728-2736. http:/ dx.doi.org/10.1002/hyp. 7094. 